\title{
Concepts of Health in Nursing Education in Undergraduate Schools of Brazil and Portugal
}

\author{
Cláudia Regina Lima Duarte da Silva ${ }^{1}$ \\ Maria Arminda da Silva Mendes Carneiro da Costa ${ }^{2}$
}

\begin{abstract}
This article represents an extract of my PhD research regarding the concepts of health present in undergraduate schools of nursing of Brazil and Portugal. The objective of this research was to comprehend how the concepts of health are explicit in the documents of undergraduate courses and how they are expressed in the discourses of the nursing professors and students. For this, thematic content analysis was used to analyze the professional education of the nurses and the concepts of health present in the nursing courses. The presentation of the results was performed using the Collective Subject Discourse technique. The results showed that in the state of Santa Catarina in Brazil, the concepts of health follow the National Curriculum Guidelines and there is an emphasis directed towards reflection on the Brazilian National Health System (SUS); while in the city of Porto, in Portugal, these concepts follow the Study Plans of the Nursing courses and emphasize nursing care both for the healthy and the sick person. The data also reveal a concern in the construction of the concept of people-centered healthcare.
\end{abstract}

Descriptors: Health; Nursing; Education, Nursing.

\footnotetext{
${ }^{1}$ RN, Ph.D. in Nursing, Professor, Universidade Regional de Blumenau, Departamento de Enfermagem, SC, Brazil. E-mail: duarte@furf.br.

${ }^{2}$ RN, Ph.D. in Science Education, Professor, Escola Superior de Enfermagem do Porto, Portugal. Researcher, UnIFAI (Unidade de Investigação e Formação sobre Adultos e Idosos), Portugal. E-mail: arminda@mail.esenf.pt.
}

Corresponding Author:

Cláudia Regina Lima Duarte da Silva

Universidade Regional de Blumenau. Departamento de Enfermagem.

Rua Antônio da Veiga, 140

Bairro Victo Konder

CEP: 89012-900 Blumenau, SC, Brasil

E-mail: duarte@furb.br 


\title{
Concepções de saúde na educação em enfermagem em escolas de graduação do Brasil e Portugal
}

Este artigo representa um recorte de pesquisa de doutorado a respeito das concepções de saúde, presentes em escolas de graduação em enfermagem do Brasil e de Portugal. 0 objetivo foi compreender como as concepções de saúde estão explícitas nos documentos dos cursos de graduação e de que forma se expressam nos discursos dos professores e estudantes de enfermagem. Para tanto, utilizou-se análise de conteúdo temática sobre a educação profissional dos enfermeiros e sobre as concepções de saúde presentes nos cursos de enfermagem. A apresentação dos resultados foi realizada através do Discurso do Sujeito Coletivo. Os resultados apontaram que, no Estado de Santa Catarina, no Brasil, as concepções de saúde seguem as Diretrizes Curriculares Nacionais e há ênfase dirigida à reflexão sobre o Sistema Único de Saúde; enquanto na cidade do Porto, em Portugal, tais concepções seguem os Planos de Estudos dos Cursos de Enfermagem e se enfatiza o cuidado de Enfermagem tanto à pessoa saudável quanto à doente. Os dados revelam, ainda, preocupação na construção do conceito de saúde centrado na pessoa.

Descritores: Saúde; Enfermagem; Educação em Enfermagem.

\section{Concepciones de la salud en la educación de enfermería en escuelas de graduación de Brasil y Portugal}

\begin{abstract}
Este artículo representa una parte de la investigación que realicé durante el doctorado sobre las concepciones de salud presentes en escuelas de graduación en enfermería de Brasil y Portugal. El objetivo de esta investigación fue comprender como las concepciones sobre la salud están explícitas en los documentos de los cursos de graduación y de qué forma se expresan en los discursos de los profesores y estudiantes de enfermería. Para esto, utilizamos el análisis de contenido temático sobre la educación profesional de los enfermeros y sobre las concepciones de la salud presentes en los cursos de enfermería. La presentación de los resultados fue realizada a través del Discurso del Sujeto Colectivo. Los resultados apuntaron que, en el estado de Santa Catarina, en Brasil, las concepciones de salud siguen las Directrices Curriculares Nacionales y existe un énfasis dirigido a reflexionar sobre el Sistema Único de Salud; en cuanto en la ciudad de Porto, en Portugal, esas concepciones siguen los Planos de Estudios de los cursos de Enfermería y se enfatiza el cuidado de Enfermería tanto a la persona saludable como a la enferma. Los datos revelan, también, una preocupación en la construcción del concepto de salud centrado en las personas.
\end{abstract}

Descriptores: Salud; Enfermeria; Educación en Enfermería.

\section{Introduction}

Health is a concept about which there is no uniformity of positions. The definitions end up being incomplete, because life is dynamic, and the person just feels in good health when s/he feels not only adapted to the environment and its demands, but also is able to follow standards of living ${ }^{(1)}$. Nursing is a health profession. This fact alone already implies the need to broaden the comprehension of the meaning of the term health. Health, as a positive concept, emphasizes the mobilization of social and personal resources and physical abilities. It is a resource for social, economic and personal development, as well as an important dimension of quality of life ${ }^{(2)}$. Health is contemplated in the projects of happiness of people from lived and positively valued experiences as a means to achieve happiness $^{(3)}$. In this sense, men and women assume the 
role of protagonists with respect to health promotion, since they are considered potentially able to control the factors that determine it, though sometimes the very concept of health may not seem clear to them. One possible reason for this is that they often use certain concepts of health in an abstract, idealized and theoretical way, without having sufficient and complete understanding and comprehension of what they mean ${ }^{(4)}$ both from a general perspective (collective), and from an individual perspective, which is because "To comprehend health from the perspective of the other is a challenge. To listen to the other, to permit him to show himself, represents more than a confrontation of concepts, but the possibility to extend them through the incorporation of the knowledge contained in the other"(5).

The existing gap in relation to the construction of a concept of health in Nursing is not a problem unique to this professional category, as in disciplines that constitute the so-called health field, there is a greater concentration of efforts to produce biomedical models of pathology, with mechanical inspiration that, by emphasizing the levels of individual analysis, end up reducing the scope of their contributions(6). This work originates from concerns about the training of nurses and includes a reflection on the concept of health which is explicit in the documents of the graduation courses and which is drawn from the discourses of Nursing professors and students. The research, partially developed in Brazil, in the state of Santa Catarina, and partially in Portugal, in the city of Porto, during the period of the international doctorate training program with a CAPES scholarship, in the Escola Superior de Enfermagem do Porto, involved the confrontation of data obtained in these two research contexts.

The state of Santa Catarina contains 95,442.9 $\mathrm{km}^{2}$ and 5,356,360 inhabitants, occupies an area of $95,346 \mathrm{~km}^{2}$ and has a coastline of about $450 \mathrm{~km}$, or approximately half of the continental coast of Portugal. In this State a concern is observed regarding the training of nurses effected on the basis of the National Curriculum Guidelines $^{(7)}$ for this purpose. Santa Catarina is one of the 27 federal units of Brazil that develops the guidelines of the Brazilian National Health System (SUS) ${ }^{(8)}$.

Portugal has 10,945,870 inhabitants, a land area of $92,391 \mathrm{~km}^{2}$ and has been part of the European Union since 1986. The European Union (EU) is an economic, political and social bloc, currently comprising 27 member states. Porto is the second largest city of Portugal and is considered the capital of the north of the country. It is located on the right bank of the River Douro. The city has approximately 350,000 inhabitants, however, the metropolitan area has approximately 1.2 million inhabitants.

The Escola Superior de Enfermagem do Porto is a non-integrated, public institution of polytechnic higher education, resulting from the merger of the D. Ana Guedes, Cidade do Porto and São João Higher Education Nursing Schools, all based in Porto. Established on 1 January 2007, the School became part of a centennial history, the history of the Escola Superior de Enfermagem D. Ana Guedes. Recently, the European Union, in the Treaty of Bologna, has demanded the adaptation of training of health professionals to the new model of organization of higher education. The central issue highlighted by the Treaty of Bologna is a paradigm shift of education from a passive model, based on knowledge acquisition, to a model based on skills development ${ }^{(9)}$.

The universities certainly assume a relevant role in the training of health professionals, a role which is guided by discussions present in their political-pedagogic projects (PPP) regarding the nature of the professional they wish to form, the purposes/objectives to which they attend, and to who and what they are committed to ${ }^{(10)}$. In these projects, as well as in other documents of the undergraduate course, the theoretic-epistemological parameters that anchor the course, which include the concepts of health, are also highlighted. Thus, the aim of this research was to deduce and discuss: the way in which the health concepts are explicit in the documents of undergraduate courses and how they are expressed in the discourse of nursing professors and students in the State of Santa Catarina and the Escola Superior de Enfermagem do Porto in Portugal.

Other recent studies and publications, between 2008 and 2009 in the database of the Virtual Health Library, demonstrate concern with the discussion of health concepts and the training of the professionals working in this area.

The training of nurses is molded from a dialectical relationship between Education, Health and Teaching. In this triage knowledge is essential, for both health and education professionals, committed to training new nurses(11). Nursing is often challenged to find ways to respond critically, in an effective way, to the health issues that are placed in life in society ${ }^{(12)}$.

The knowledge of nursing in collective health has been driven by deepening the theoretical-methodological references ${ }^{(13)}$. The technological transformations have brought changes in society, in their more diverse 
contexts, especially in the health field, requiring new competences, critical thinking and decision making skills from its professionals ${ }^{(14)}$. This study contributes to reinforcing the existing interfaces between health and nursing education, with a view to the construction of epistemological bases for the establishment of a more positive view of health for the practice of the nurse due to the link between thought and action.

\section{Methodological Steps}

This research was developed based on a qualitative approach, using thematic content analysis(15), involving the prior definition of two themes: health concepts in nursing education and professional education of nursing students. Data were organized using the Collective Subject Discourse $(C S D)^{(16)}$, as a practical way of collecting and describing qualitative data of a discursive nature. For the elaboration of the Collective Subject Discourse, the discourses were used in their raw state, after an analytical study of decomposition that basically consisted of the selection of the main anchorages, which are explicit linguistic manifestations of a given theory or ideology used by the speaker to "frame" a specific situation and/or central ideas.

The survey was conducted in eight Nursing undergraduate degree courses in Santa Catarina Brazil, of the 27 existing ones, according to the criteria of geographical distribution of courses by Mesoregions, population coverage, character of the institution, number of spaces offered, length of existence of the courses and curriculum proposal. In Portugal, the criterion was the existence of a partnership with the Federal University of Santa Catarina (UFSC) and the historical moment of merging of the three schools that had united to form the Escola Superior de Enfermagem do Porto - Portugal, composed of three sites - São João, Cidade do Porto and D. Ana Guedes.

In total, 34 subjects were interviewed, 24 in Brazil and 10 in Portugal. Among the interviewees, 11 were coordinators of the Nursing courses and therefore performed a didactic-pedagogical function in the courses concerned; 12 were nurse professors responsible for addressing content regarding explicit health concepts in the syllabus of the disciplines or modules developed by them in the courses in which they operate; and 11 were students of the last phase of each course. Interviewing students nearing completion of course was preferred because, in comparison with others, these had had more contact with the contents that address concepts of health.
The Collective Subject Discourse is expressed through a discourse delivered in what might be called the first person (collective) of the singular. This is an I syntax which, at the same time that it signals the presence of an individual subject of discourse, expresses a collective reference, to the extent that $I$ speaks for or on behalf of a collectivity ${ }^{(16)}$.

The analysis of thematic content involves establishing a structured process of analysis to validate or conceptually extend a theory. This relates semantic structures with sociological structures of the utterances, reaching a deeper level of analysis, which exceeds the manifest meanings. Initially, the researcher defines key concepts, themes or categories of analysis. In the case of this research, the issues related to the concepts of health that can be inferred from the documents of the undergraduate courses, through documental research, and from the discourse of the interviewees. These themes included: the ideal of the nurse; the way that the concept of health is addressed in the training of the nurse; and experiences in moving towards a concept of health in Brazil and Portugal.

In Santa Catarina, the plans of the course and political-pedagogic projects that contained the conceptual framework and the profiles of ex-students - professionals were analyzed. The syllabi contained in the teaching plans were used to collect data on the disciplines and modules that address the concept of health. In the Escola Superior de Enfermagem do Porto ESEP - explicit information in study plans and orientation guides of the disciplines and modules was collected. Then, for the analysis of explicit health concepts in the discourses of professors and students of the Nursing course, semistructured interviews were conducted with coordinators, nurse professors and students of the undergraduate Nursing course of Santa Catarina and of the Nursing teaching courses in the three sites of the Escola Superior de Enfermagem do Porto.

At all stages of this study ethical issues were a concern, taking into consideration Resolution No. 196/96(17), regarding research involving human beings. Approval was obtained by the Ethics Committee of the Federal University of Santa Catarina under number $347 / 2006$. The research proposal was presented to all interviewees, who read and signed the terms of free prior informed consent.

\section{Presentation and analysis of the data}

A characteristic of the trajectory of the training in nursing in Santa Catarina is the decentralization of 
the courses of some Higher Education Institutions. In Portugal, the public health system is not emphasized, the major concern is to train nurses who can provide general nursing care to a healthy or sick person. Brazilian and Portuguese students have a high visibility curriculum. In both countries, appearing in the syllabi of disciplines and modules that address the concept of health are, the collective and community context, the health-disease process, family health and nursing care in basic health units. In Portugal, the emphasis is on environmental health, virtually unexplored in Brazil. There the individual learning process is greatly valued based on the confrontation with the unknown and overcoming challenges to the personal growth of the student. In Brazil, the approach is to transform the model of healthcare and there is an insistence on reflection regarding the reality of the health of the population.

\section{The ideal of the nurse in Brazil and Portugal}

In both countries the desire is to form generalist professionals. However, the connotation of the term generalist is distinct. While in Brazil to be a generalist has to do with the training of nurses to intervene in the health-disease process in an integral way, as seen in the excerpt below, taken from the survey data:

Central idea: To train nurses to intervene in the healthdisease process in an integral way (document)

CSD 1 - To form generalist nurses to intervene in the health-disease process in an integral way, to act at all levels of healthcare for the individual and the collective, and who comprehend nursing as the art and science of people living with and caring for others. To develop professional competence through the following requirements: self-growth and scientific attitude, commitment to the socio-economic-political-cultural reality of the population. To prepare future nurses to develop competencies and skills in care, management and research. (course 1, course 2, course 4, course 7. Santa Catarina).

In Porto, the term generalist means a professional with knowledge and capacity of comprehension in the area of nursing, that develops the scientific rigor, is communicative, possesses technical dexterity, has professional motivation, is open to the world and understands the social role of the profession.

In Portugal, practical experience of the future professional is valued as a way to develop skills that enable life-long learning with a high degree of autonomy. In Santa Catarina, the training strengthens the expectation that the future professional is critical and reflective and develops leadership capabilities.
In the latter context, a commitment to improving the quality of life of the population and the principles of the SUS is also expected. The Brazilian students say they have grown in their personal and professional lives from the privileged contact with people, they highlight the human side of nursing expressed by the integral vision of the human being. Therefore, the good nurse is one who would act, in the performance of the profession, with professionalism and responsibility, as verified in the excerpt below.

Central idea: the good nurse would be one who knows how to do things well with accuracy, professionalism and responsibility (interview)

CSD 48 - A good nurse is one who is able to be attentive to the context, to the climate, whether of the institution, or of the service where they work, therefore the reality of that person of who they will care. It is the one who knows how to do well, i.e. knows how to take care of the other well, with rigor in technical terms, to do things with responsibility, professionalism, according to his demands and those of his profession and of the others. Parallel to this also to know how to communicate. (professor 1 ; professor 2; professor 4. Cidade do Porto).

Conversely, the Portuguese students highlight the scientific and human character of the profession and the community action. They assert that nurses have a privileged contact with patients, making them become professionals who know how to be with the other and to manage nursing care to a healthy or sick person.

\section{The way the concept of health is approached in training of the nurse in Brazil and Portugal}

In Santa Catarina, some health concepts used in the undergraduate courses in nursing are based on the Organic Law of Health. From the data analysis, a tendency to adopt a more holistic perspective to the concept of health was also inferred. The inclusion of this concept in the curriculum of the courses in Santa Catarina starts from the first phase, with the integration of the concept of health that the student already brings with them. The way to approach the concept of health is discussed by professors in the PPP of the undergraduate courses, where they cite, however, that there are communication difficulties in the process of reflection regarding this concept. There exist doubts about the diligence with which professors make the integration of the concept of health throughout the course. In these documents (PPP), the SUS is mentioned, in Santa Catarina, when talking about the non-fragmentation of knowledge, by virtue of the principle of integrality that guides its operation. 
The reality described in the documents analyzed during the research shows that to facilitate the process of elaboration of the concept of health seems to be the responsibility of the area of collective health. The fact that in the hospital area the concept of health is slightly forgotten appears as a central idea, however, all courses show that they focus on this concept from the first phase or year, being discussed in the following years of training. In Portugal, the concepts of health arise from the syllabi of the courses in nursing teaching and from the orientation guides of the disciplines and modules. The data analysis allowed the realization that, as is clear in the passage mentioned below and obtained during the interviews, the concept of health is seen from a psychosocial perspective.

Central idea: The concept of health is seen from a more holistic, psychosocial perspective (interview)

CSD 75 - The concept of health here is seen in a perspective today, as a psychosocial perspective, a holistic perspective, i.e. we do not see. Today, the person feeling sick is more important than only the diagnosis of the pathology. When a person feels sick, whether she is really sick or not, it may be, may not be a physical illness, with clear diagnosis, but there is something that is not good with her (coordinator 1. Cidade do Porto).

In Portugal, the concept of health is considered complex and it is stated that the school is based on the salutogenic model. Its inclusion in the curriculum occurs from the first year of the course and the professors responsible for disciplines and modules that address the concept of health, for the most part, have training in community health. This concept is discussed by the professors of the curricular units and then between coordinators. However, there is doubt whether all the professors are concerned with integrating the concept of health throughout the course.

\section{Experiences in moving towards a concept of health in Brazil and Portugal}

In Santa Catarina, quality of life is mentioned in the discourse of the nurses regarding the provision of global care to people. The students comprehend what the professor teaches them, as a result of accessibility and of flexibility, making education more enjoyable.

Still moments of frustration occur during the training when the nurse judges not to have done well in the practice of healthcare, has not matched the expectations of the patient, of the group and of requirements in the training process. The need to be persistent, focused and to have goals in life, was reinforced, considering that those who follow the nursing profession suffer and are very pressured.

Central idea: Have managed to help that person feel happier (interview)

CSD 85 - It is the contact, the contact with the patients, I think we learn a lot, the classes are especially important for basic training, mainly to arouse in us a critical spirit and to reflect and enable us to know the context of the practice. What I consider most important, was to have managed to help that family, to have managed to help that person feel happier (student 1; student 2; Cidade do Porto).

In Portugal, the need for nurses to learn to cope professionally with death was mentioned. As less pleasant experiences, the students report that they perceived a certain reduction in the view of the role of nurse and stress that nursing is a profession that intends to get to the individual. Regarding the positive experiences that occurred during classes and internships, the concern of the professor with the human being and not just the technical part was highlighted, because the future professionals should go beyond physical pain and comprehend the context of the person. Help for people is seen as an opportunity for personal growth. Added to this is the need for and pleasure in helping people feel happier.

\section{Final considerations}

The contexts of research have proved different, both in their antiquity, both in their socio-cultural insertion: this may relate to some statements that emphasize the specific site of the construction of the concept of health. The historical context of Higher Education Institutions offering undergraduate and teaching courses in nursing shows us that in the city of Porto, the training of nurses was initiated in 1901 to meet the needs of training people for the hospitals of the city. In Santa Catarina, the Federal University of Santa Catarina was the first Institution of higher education to offer training in this area.

The normative politics and curriculum of the contexts studied proved to be different in their approaches to the concept of health, especially the Political Pedagogical Project in Santa Catarina and the Treaty of Bologna in Portugal. The expected profile of the Brazilian nurse is one where the profession is critical, reflective and develops leadership in the area. The nurses of Porto highlight the privileged contact with the patients, the fact of being a professional who knows how to be with 
the other and manage the general nursing care of the healthy or sick person.

The area of collective health figures prominently in the discussion of the concept of health. For the students, moving toward the construction of the concept of health is related to the technical training of the profession. The collective and community context, the health-disease process, family health and nursing care in the basic health units are present in the syllabi of the disciplines and modules that address the concept of health, both in Brazil and Portugal. In Santa Catarina, the emphasis was the concept of quality of life and in the city of Porto it was the need to learn to understand death due to the ageing population of Portugal.

The curricular benchmarks of the undergraduate courses in nursing in Brazil express concepts of health resulting from guidance documents at the national level, such as the Constitution of the Republic. The main elements, characteristics and origins of health concepts that are found in the documents of the nursing courses of Santa Catarina, are based on the Organic Law of Health and on the National Curriculum Guidelines. Ways of looking at reality are differentiators in the construction of the concept of health in both contexts: in Brazil, the reflection of the reality of the health system is emphasized and in Portugal, the self-construction of the student and of their concept of health is highlighted.

The data reveal a general concern in the construction of the concept of health focused on people, but can be distinguished: in Brazil, the Brazilian National Health System (SUS) is emphasized in most undergraduate courses, and in some cases appears in the objectives and specific skills to train the student to work in the area of public health; in Portugal, the public health system was not observed with the same importance. The main concern is to train nurses for general nursing care for the healthy or sick person and the concept of health is working from a psychosocial and more holistic perspective, no longer considering the concept of health as the opposite to disease but considering it as very complex and that the School is based on a salutogenic model.

In Brazil, the quality of life is present in the discourse of the nurse and of nursing care for the performance of global care of the people. There is concern for the human being when the context of the person is considered. The student comprises what the professor teaches as a result of accessibility and flexibility, which makes education enjoyable. The need to have persistence, effort and purpose of life was reinforced considering that the nursing profession is full of pressure and suffering.

In the experiences of moving towards a concept of health in Portugal, the need was cited for the nurse to learn to cope with death and develop self-control. The concern was highlighted of the professor with the human being and not with the technique due to the greatness of the first faced with the second. In general, Brazilian and Portuguese students refer to having a clear vision of the course in which they take part. In Brazil, the change in the model of healthcare is a constant concern due to reflections of the reality of the health services offered to the population. In Portugal there is a valorization of the individual learning process, based on the confrontation with the unknown.

The development of a multicenter study, in the contexts of Santa Catarina and Porto, in addition to personal enrichment, has been useful and promising, with prospects of expanding the partnership between institutions and countries. The deepening of the remaining data can represent an added value, to deepen new perspectives of the concept of health and to develop new research projects.

\section{References}

1. Canguilhem G. O normal e o patológico. 5 ed. Rio de Janeiro: Forense universitária; 2002.

2. Carta de Ottawa. Primeira Conferência Internacional sobre Promoção da Saúde. Canadá, nov. 1986. [acesso: 03 nov 2008]. Disponível em: http://www.opas.org.br/coletiva/uploadArq/ Ottawa.pdf.

3. Wegner W, Pedro ENR. Concepções de saúde sob a ótica de mulheres cuidadoras-leigas, acompanhantes de crianças hospitalizadas. Rev. Latino-Am. Enfermagem. 2009;17(1):88-93.

4. Lunardi VL. A ética como o cuidado de si e o poder pastoral na enfermagem. Pelotas: UFPel; Florianópolis: UFSC; 1999.
5. Martin VB, Angelo M. Significado do conceito de saúde na perspectiva de famílias em situação de risco pessoal e social. Rev. Latino-Am. Enfermagem. dez 1998;6(5):45-51.

6. Almeida FN de. O conceito de saúde: ponto-cego da epidemiologia? Rev Bras Epidemiol. abril-dezembro 2000;3(1/3):4-20.

7. Conselho Nacional de Educação (BR). Resolução CNE/CES no 3, de 7 de novembro de 2001. Institui Diretrizes Curriculares Nacionais do Curso de Graduação em Enfermagem. Conselho Nacional de Educação Superior. [acesso: 30 outubro 2008] Disponívelem: http://www.anaceu.org.br/legislacao/resolucoes/ reso3_07-11-2001.html 
8. Lei Orgânica da Saúde no 8.080 (BR). Brasília. 1990.

9. Tratado de Bolonha. Bolonha, junho. 1999. [acesso: $15 \mathrm{abr}$ 2010]. Disponível em: http://www.crue.org/decbolognaingles. htm

10. Bagnato MHS. Formação crítica dos profissionais da área de enfermagem. Texto \& Contexto-Enferm. janeiro-abril. 1999;8(1):31-42.

11. Resck ZMR, Gomes ELR. A formação e a prática gerencial do enfermeiro: caminhos para a práxis transformadora. Rev. Latino-Am. Enfermagem. jan-fevereiro; 16(1)71-7.

12. Silva AL. A enfermagem na era da globalização. Rev. LatinoAm. Enfermagem. jul-ago 2008;16(4):787-90.

13. Nakamura E, Egry EY, Campos CMS, Nichiata LYI, Chiesa AM, Takahashi RF. The potential of an instrument to identify social vulnerabilities and health needs: collective health knowledge and practices. Rev. Latino-Am. Enfermagem. 2009;17(2):253-8.
14. Carvalho EC. Desafios no desenvolvimento de competências de enfermeiros. Rev. Latino-Am. Enfermagem. set-out 2008;16(5): 799-800.

15. Hsieh H-F, Shannon SE. The approaches to qualitative content analysis. Sage Journals Online and HighWire Press Platforms. Qual Health. Res. 2005 nov; 15:1277.

16. Lefévre F, Lefévre AMC. Discurso do sujeito coletivo: um novo enfoque em pesquisa qualitativa (desdobramentos). 2 ed. Caxias do Sul: Educs; 2005.

17. Conselho Nacional da Saúde (BR). Resolução n. 196/96. Diretrizes e Normas regulamentadoras sobre pesquisa envolvendo seres humanos. Diário Oficial da República Federativa do Brasil, 10 out 1996. 